\title{
Comparing Between Best Energy Efficient Techniques Worldwide with Existing Solution Implemented in Al-Ahliyya Amman University
}

\author{
Ammar Alkhalidi $^{a}$, Walaa Hassan ${ }^{b, *}$ \\ ${ }^{a}$ Energy Engineering Department, German Jordanian University, Amman, Jordan \\ ${ }^{b}$ Department of Mechanical Engineering, Jordan University of Science and Technology, Irbid, Jordan
}

\begin{abstract}
In this research paper, an overview of energy reduction methods around the world in commercial buildings was investigated, to find out the best solution for minimizing electricity demand of Al-Ahliyya Amman University (AAU). Those methods are renewable energy technologies mainly wind and photovoltaics (PV) system using either conventional or Carbon Nanotubes panels, building envelope system mainly dynamic Insulation materials and cool roof coating and National country system mainly demand response program and energy consumption ration. According to the overview, the best-promised method solution to achieve the target of saving, reducing investment cost and carbon emissions in AAU is the Standalone Hybrid Carbon Nanotubes PV system. This method was compared with the existing on-grid PV system project applied in AAU. The comparison was based on investment cost, payback period and solar cell efficiency. The comparison analysis results revealed that Standalone Carbon Nanotube PV system was able to save $21.12 \%$ of the investment cost when compared to the existing AAU project with a reduced payback period from 10 to 8 years and Internal Rate of Return (IRR) of $16 \%$.
\end{abstract}

Keywords: carbon Nanotube PV system, Energy Efficient Techniques, Amman Jordan.

\section{Introduction}

Fossil fuels are the primary non-renewable energy source for all technology and industrial development around the world such as oil, gas, and coal. It accounts for $80 \%$ of the total energy consumption in the world [1]. Only $30 \%$ to $40 \%$ of the total energy consumed is being utilized by commercial Buildings [2]. The major two loads that account for $50 \%$ of the total energy demand are heating and cooling [3]. According to the International Energy Agency (IEA), the overall world needs of primary energy source will increase by 2040 which means the price of oil for the next 22 years will reach \$215/barrel. In addition to the increasing amount of carbon emissions [4]. As a result, energy policies start to introduce energy efficiency concept and clean environment. The principal purpose of these policies is to distribute energy awareness among communities, reduce energy consumption and electricity bill, reduces issues related to the climate change and national energy security [5].

\section{Improvement of Energy Efficiency in Commercial Buildings}

Commercial building sectors include offices, education, hotels, warehouses, government buildings, hospitals, retail, and services. The improvement of energy efficiency in these buildings has shown significant attention in the last decade around the world to reduce dependency on fossil fuel resources and minimize electricity consumption [6]. Therefore, several energy efficiency solutions applied by several countries around the world in commercial buildings such as China, Ireland, USA, Malaysia, Pakistan, Mexico, Australia, Algeria, and Jordan have been overviewed. The overview is based on three categories: category I for renewable energy technologies solutions, category II for building Envelope system solutions and category III for Country National systems solutions.

${ }^{*}$ Corresponding author. Tel.: +962799602045

Fax: + 96227095123; E-mail: wlla_unique@outlook.com

(C) 2018 International Association for Sharing Knowledge and Sustainability

DOI: 10.5383/ijtee.17.01.001 


\subsection{Category I: Renewable Energy Technologies}

Algeria, Mexico, India, and Jordan have conducted a research study in renewable energy technologies. In Algeria, fuel consumption has been reduced to $70 \%$ by implementing a Hybrid PV-Diesel power wind battery system [5]. While in Mexico, $49 \%$ of the annual energy for both new and existing commercial building using various combinations of energy efficiency measures (EEM) and PV sizes [7]. In India, the installation cost of the PV system has been reduced to the half using Nano-solar PV panel [8]. Furthermore, the overall efficiency of the solar cell has been increased to the $31.25 \%$ using Carbon Nanotubes (CNT) anti-reflection coating material at the surface of the solar cells [9]. While in Jordan, rooftop PV solar system has been implemented in Al-Mutah University and AAU to supply electricity demand, reduce energy consumption with performance ratio above $80 \%$ [10], [11].

\subsection{Category II: Building Envelope system}

USA, Australia, and Pakistan have conducted a research study in reducing energy consumption using building Envelope system. In the USA, $17 \%$ of the annual heating and cooling energy costs has been reduced for office buildings using Dynamic Insulation Materials (DIMs). It reduces heating and cooling loads in buildings in a wide range of climate conditions [12]. In Australia, an amount of 6.5-8.4 $\mathrm{kWh} / \mathrm{year} / \mathrm{m}^{2}$ of energy with $2680 \mathrm{~kg}$ of $\mathrm{CO}_{2}$ emissions per warehouse building has been saved using cool roof coating. It reflects a maximum amount of sunlight and absorbs less heat [13]. In Pakistan, $47 \%$ of the energy for a commercial plaza has been saved using Efficient Electric Lights mainly LEDs as a replacement for old traditional energy consuming bulbs such as fluorescent lamps [14].

\subsection{Category III: National Country System}

China and Ireland have conducted a research study in reducing energy consumption using National Country system. For example, China government's uses Energy Consumption Ration (ECR) value as a benchmark to enhance energy efficiency and saving for building activities. ECR means the minimum energy needed to operate a building under comfortable conditions [15]. While Ireland is using Demand Response Program between the utility and customers by reducing the energy consumption during times when the supply is low, or demand is high on the grid. It also rewards building applying for the program [16], [17]. Researchers in Category I have studied the contribution of renewable energy technologies mainly wind energy and solar photovoltaic system using both conventional and CNT photovoltaics panels to minimize fossil fuel reliance, energy consumption and investments cost [5], [7], [8], [10], [11], [18]. While researchers in Category II agree that improvement in the building Envelope system by either applying DIMs, cool roof coating or Efficient Electric Lights technology would save more than $60 \%$ of the annual heating and cooling and reduce carbon emissions [7], [12]-[14]. Researchers in Category III have solved the energy consumption issue in different ways using National Country system mainly Demand Response Program [16], [17] and ECR [15].

This paper combines Standalone Hybrid system using CNT photovoltaics panels. As a most promising solution applied in the AAU to reduce its electricity demand. Then compare it with an existing solution in AAU. The comparison will be based on the investment cost, payback period and solar cell efficiency.

\section{Methodology}

\subsection{Site Information}

Al-Ahliyya Amman University (AAU) is located in Al-Sarw region between Amman and Al-salt city [10] $\left(32^{\circ} 03^{\prime} 00 " \mathrm{~N}\right.$, $35^{\circ} 43^{\prime} 12$ "E, the altitude of 795m and GHI of $6.19 \mathrm{KWh} \cdot \mathrm{m}^{2}$ [19]. The university consists of seven buildings, five students housing and cultural Foundation Forums (ARENA) with an overall area of $7268 \mathrm{~m}^{2}$. The promised system is located in the carport area of the car parking with an overall area of $4.3125 \mathrm{Km}^{2}$. The annual energy consumption is $4 \mathrm{GWh}$ [10] with monthly bill cost of 2000JD [11].

Figure 1 shows the energy consumption facilities at the AAU university as $52 \%$ of the electricity consumption is being utilized by the pumping system, lighting systems, water chiller, air conditioning and female residence [10].

\subsection{System Description}

The Standalone Hybrid CNT PV system has been chosen because the power generated by the solar system will supply the AAU during daytime hours with backup batteries for either cloudy days or emergency night use at the same time connected to the grid. In addition to that, it supplies the utility grid with the excess power that is beyond the consumption by the connected load. The system is composed of CNT PV panels, inverters, batteries, battery charge controller, cables and supporting mounting structure connected to the electrical grid system [11].

\subsection{Comparison between carbon nanotubes and ET- P660235 PV panels used in AAU}

The ET-P660235 panel used by AAU has two major drawbacks: low efficiency since cell efficiency does not exceed $14.44 \%$ as a result $30 \%$ of the total incident energy is reflected [20] and expensive manufacture cost since average cell cost per $\mathrm{KWp}$ is 1.59JD/Wp [8]. The issue of cost and efficiency has been solved using a dye-sensitized solar cells (DSSCs) cover by antireflection coating chemical material called Carbon Nano Tubes (CNT). The average cost of Carbon Nano cell is $0.53 \mathrm{JD} / \mathrm{Wp}$ [8] with the overall performance of solar cell efficiency is $31.25 \%$ [9].

\subsection{Carbon Nanotubes operation}

The dye-sensitized Nano solar cells work as when the solar irradiation hit the solar cell, the dye catches the photons since the dye is mainly the photoactive material of the DSSC and can produce electricity once it is sensitized by lights. After that, the electron of the dye gets excited and move into titanium dioxide (TiO2) conduction band where direct current generated as shown in figure 2 . This dye-sensitized Nano solar is covered by thin layer anti-reflection coating material on the surface of the solar cell with a certain chemical called Carbon Nanotubes (CNT). This chemical material is able to absorb the maximum amount of photons by minimize the reflections of the solar radiation, reduce the losses and increases the overall performance of solar cell efficiency up to $31.25 \%$ higher than the (ET-P660235) AAU solar cell [9]. 
Alkhalidi \& Hassan / Int. J. of Thermal \& Environmental Engineering, 17 (2018) 1-10

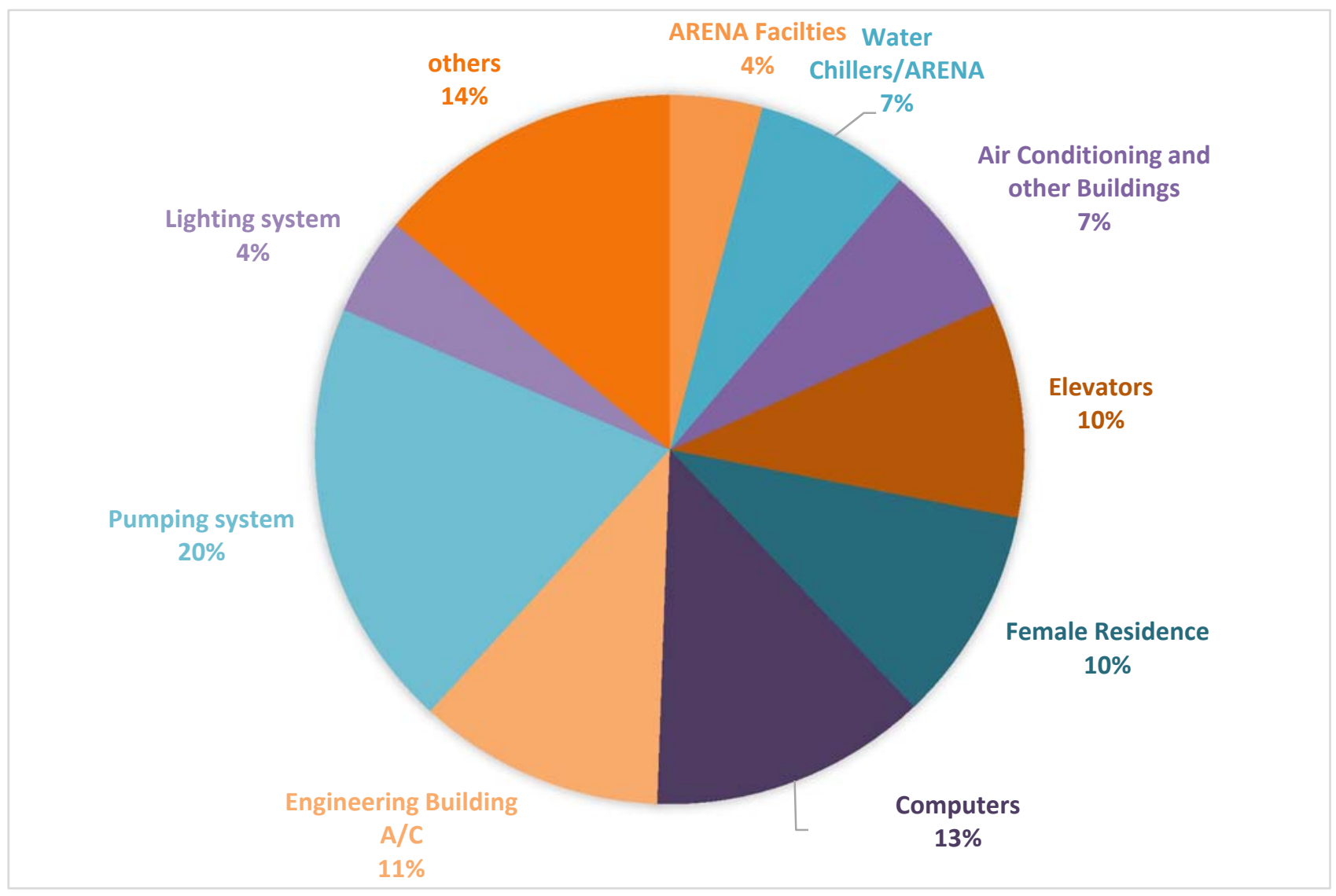

Fig. 1. Energy consumption facilities in AAU [11]

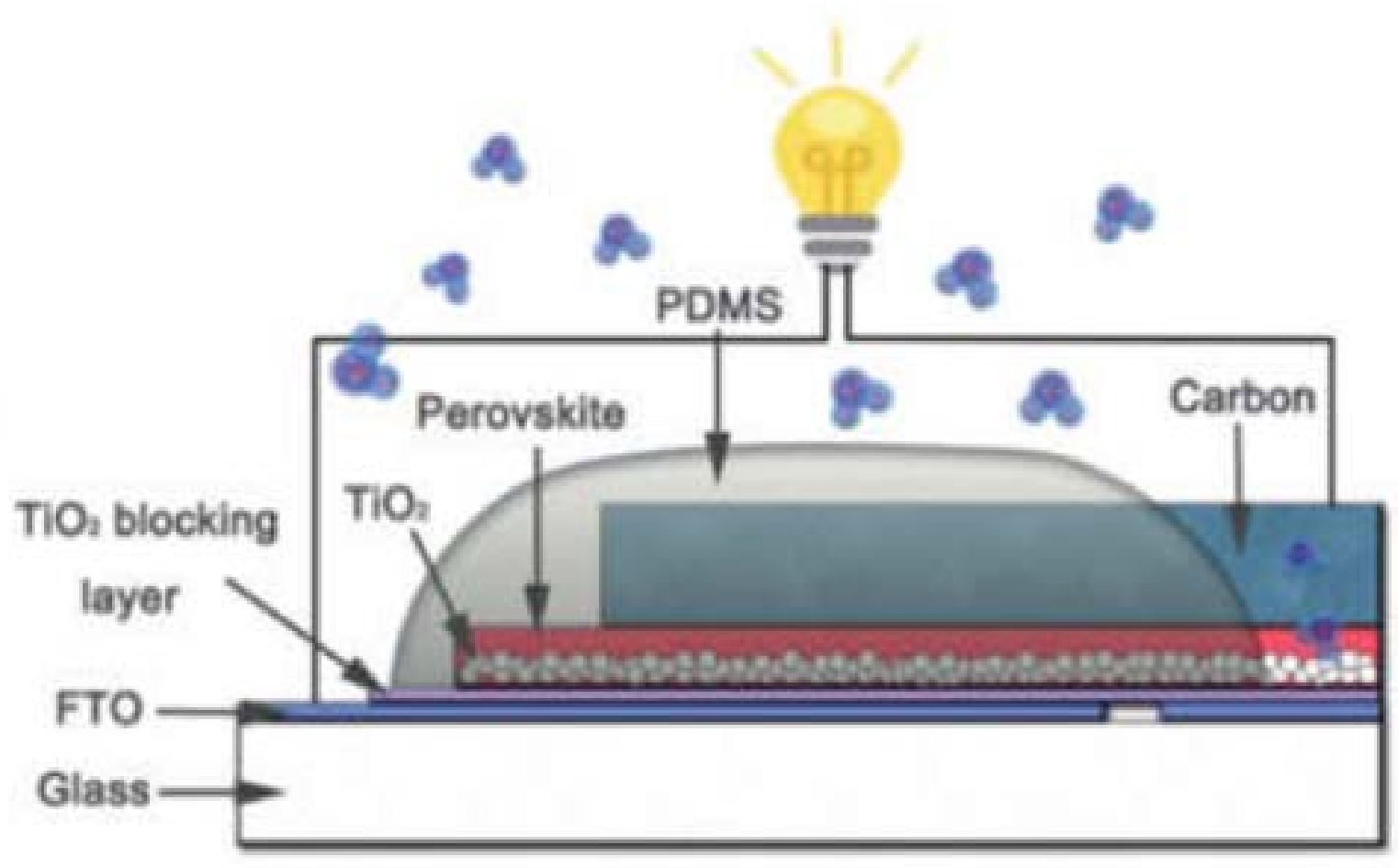

Fig. 2. dye-sensitized carbon Nanotube solar cell [21] 


\subsection{Proposed Battery Design Calculation}

\subsubsection{Determination of battery size:}

When selecting the battery size, two major factors need to be considered: days of autonomy (days without sunlight such as in winter or cloudy days) and depth of discharge (DoD) as shown in equation 1 :

$$
\begin{aligned}
& \text { Required battery bank capacity } \\
& =\frac{\text { average Wh per day } \mathrm{x} \text { days of autonomy }}{\text { Battery voltage } \mathrm{x} \text { Depth of discharge }}
\end{aligned}
$$

Now determine the number of batteries in parallel and series, batteries technical values must be available such as a nominal voltage of the batteries is needed for series configuration and ampere-hour is needed for parallel configuration: The given equation 2 and 3 for parallel and series:

Total number of batteries in series

$$
=\frac{\text { voltage of the system }}{\text { nominal voltage of the battery }}
$$

$$
\begin{aligned}
& \text { Total number of batteries in parallel } \\
& \text { battery bank Capacity (Ampere }- \text { hour (Ah)) }
\end{aligned}
$$

\subsubsection{Determination of the size of the solar array:}

The solar array must be enough to supply the load with a sufficient amount of energy that meets the average Ah load per day with the nominal operational voltage. However, sometimes some panels are not working perfectly since panels are not clean, or glass is broken so the number of the panels must be increased above the load demand requirement.

The average Ah demand per day that must supply the array to the battery is given by equation $4,5,6$, and 7 :

Average Ah per day to be supplied by the array

$=\frac{\text { daily avg taken from the battery }}{\text { efficiency of the battery }}$

Array peak amps

$$
=\frac{\text { average } \mathrm{Ah} \text { per day to be supplied by the array }}{\text { Peak Sunshine hours per day }}
$$

Panels connected in Parallels:

Panels connect in parallel

$$
=\frac{\text { array peak amps }}{\text { peak amps per modules }}
$$

Panels connected in series:

Panels connect in series

$$
=\frac{\text { battery bank storage }}{\text { nominal voltage storage }}
$$

\subsection{Geographical Information}

Table 1 shows the monthly average values of global irradiance

\begin{tabular}{|c|c|c|c|}
\hline Month & $\begin{array}{l}\text { Ambient } \\
\text { Temperature }\end{array}$ & $\begin{array}{l}\text { Solar } \\
\text { Radiation for } \\
\text { insolation } \\
\text { incident on a } \\
\text { horizontal } \\
\text { surface } \\
\left(\mathrm{KW} / \mathrm{m}^{2}\right)\end{array}$ & $\begin{array}{l}\text { Solar } \\
\text { Radiation for } \\
\text { insolation } \\
\text { incident on a } \\
\text { tilted angle } \\
\text { (30 degrees) } \\
\text { south } \\
\left(\mathrm{KW} / \mathrm{m}^{2}\right)\end{array}$ \\
\hline January & 10 & 2.85 & 3.85 \\
\hline February & 12 & 3.54 & 4.39 \\
\hline March & 18 & 4.76 & 5.29 \\
\hline April & 22 & 6.08 & 6.01 \\
\hline May & 27 & 5.98 & 6.35 \\
\hline June & 31 & 7.77 & 6.73 \\
\hline July & 34 & 7.53 & 6.66 \\
\hline August & 36 & 6.67 & 6.39 \\
\hline September & 28 & 5.7 & 6.12 \\
\hline October & 19 & 4.17 & 5.06 \\
\hline November & 17 & 3.17 & 4.19 \\
\hline December & 11 & 2.63 & 3.69 \\
\hline
\end{tabular}
on a horizontal surface (4-8) $\mathrm{KW} / \mathrm{m} 2$ and average ambient Temperature in Jordan while the incident on a tilted angle is for the Al-Sarw region. Based on table 1, the PV modules will be installed with an angle 30o south with average solar irradiation of $5.4 \mathrm{KW} / \mathrm{m} 2$ and sun peak hours (SPH) is 6 hours [10].
Table 1. Monthly average values of global irradiance on a horizontal surface [10]

\subsection{Simulation using PV SOL premium 2018}

The system simulated using PVSOL premium 2018 simulator [22] and SMA sunny design to verify the system is functioning successfully.

\section{Design, Simulation, Result, and Outcomes}

\subsection{Design and Calculation of the Standalone Hybrid CNT PV system Result:}

The car parking area based on Jordan specifications is $14.375 \mathrm{~m}^{2}$. And by assuming the parking area can accommodate 300 vehicles that the total area of the whole carport is $4.3125 \mathrm{Km}^{2}$. The CNT PV module that has been selected for this design is from Nanosolar company which is NS-100B-260W. It has a power of $260 \mathrm{Wp}$ and an area of $1.99 \mathrm{~m}^{2}$. Thus, each car park can occupy a total of 8 panels per park. Therefore, the maximum number of the PV panels for the whole carport is 2167 panels. While the maximum power generated by PV panels is $563.42 \mathrm{KW}_{\mathrm{p}}$. But since the total installed capacity for AAU is $276 \mathrm{~kW}_{\mathrm{p}}$ so only 1062 panels with only 133 parks and area of $1912 \mathrm{~m} 2$ [11] are needed to supply the load with sufficient energy. Due to the expensive cost of batteries, only $30 \mathrm{MWhr}$ /year out of $4 \mathrm{GWhr}$ /year will be used as a backup in case of emergency energy shortage or cloudy days and to minimize dependency on the grid. Therefore, calculations mentioned in part $\mathrm{E}$ of the methodology using data in table 2 has been used to find the number of the panels and batteries needed to supply a demand load of 30MWhr/year. Table 2 provides the battery rating values and NS-100B-260W module specifications used in the calculations: 
Table 2 Rating of different equipment used

\begin{tabular}{|c|c|c|c|}
\hline Battery [8] & Rating & $\begin{array}{l}\text { Module (Nano) } \\
\text { NanoPV-C-P6- } \\
\text { 260W }\end{array}$ & Rating \\
\hline \multirow[t]{2}{*}{ Voltage } & $12 \mathrm{~V}$ & $\begin{array}{ll}\text { Rated } & \text { Peak } \\
\text { power } & \end{array}$ & $260 \mathrm{Wp}$ \\
\hline & & $\begin{array}{ll}\text { Peak } & \text { power } \\
\text { Voltage } & \end{array}$ & $39 \mathrm{~V}$ \\
\hline \multirow[t]{2}{*}{ Ampere-hours } & 200Ah & $\begin{array}{ll}\text { Peak } & \text { power } \\
\text { current } & \end{array}$ & $6.7 \mathrm{~A}$ \\
\hline & & $\begin{array}{l}\text { Open } \\
\text { voltage }\end{array}$ & $48.1 \mathrm{~V}$ \\
\hline \multirow[t]{2}{*}{$\begin{array}{l}\text { Depth of } \\
\text { discharge }\end{array}$} & 0.8 & $\begin{array}{l}\text { Short } \\
\text { current }\end{array}$ & $7.3 \mathrm{~A}$ \\
\hline & & $\begin{array}{ll}\text { Max. } & \text { System } \\
\text { voltage } & \end{array}$ & $1500 \mathrm{~V}$ \\
\hline Efficiency & 0.9 & Solar cells & 84 cells \\
\hline
\end{tabular}

By using only 1 days of autonomy, 80\% depth of discharge, $230 \mathrm{~V} / 50 \mathrm{~Hz}$ for voltage and frequency system in Jordan, 6 peak hours [10] and total demand load per year 31MWhr/year (86.656KWhr/day). Table 3 shows all the panels and batteries needed for the backup design using the proposed battery bank equations mentioned in part $\mathrm{E}$ of methodology. Table 3 shows an economic analysis comparison for Standalone Carbon Nanotubes system and existing AAU system.

Table 3 Calculations of Nano solar battery system [8]

\begin{tabular}{|c|c|c|c|c|}
\hline 1 & $\begin{array}{l}\text { Battery } \\
\text { bank } \\
\text { amp/Ah }\end{array}$ & $\begin{array}{l}\text { (Avg Wh/day } \\
\text { days of } \\
\text { autonomy)/system } \\
\text { Voltage }\end{array}$ & $\begin{array}{l}86656 x 1 \\
230\end{array}$ & $\begin{array}{l}377 \\
\text { Amph }\end{array}$ \\
\hline \multirow[t]{2}{*}{2} & \multirow{2}{*}{$\begin{array}{l}\text { Total } \\
\text { Battery } \\
\text { bank } \\
\text { Capacity } \\
\text { per day }\end{array}$} & \multirow[t]{2}{*}{$\begin{array}{l}\text { Battery bank } \\
\text { Amph/DOD }\end{array}$} & $\begin{array}{l}377 \\
\text { Amph }\end{array}$ & \multirow{2}{*}{$\begin{array}{l}472 \\
\text { Amph/day }\end{array}$} \\
\hline & & & 0.8 & \\
\hline 3 & $\begin{array}{l}\text { Batteries } \\
\text { in series }\end{array}$ & $\begin{array}{l}\text { System } \\
\text { Voltage/battery } \\
\text { voltage }\end{array}$ & 230/12 & 20 \\
\hline \multirow[t]{2}{*}{4} & $\begin{array}{l}\text { Batteries } \\
\text { in } \\
\text { parallel }\end{array}$ & $\begin{array}{l}\text { Ah of battery } \\
\text { bank/Ah of } \\
\text { battery }\end{array}$ & $472 / 200$ & 3 \\
\hline & $\begin{array}{l}\text { Total } \\
\text { No. of } \\
\text { batteries }\end{array}$ & $3 * 4$ & $20 \times 3$ & $\begin{array}{l}60 \\
\text { batteries }\end{array}$ \\
\hline \multirow[t]{2}{*}{5} & \multirow{2}{*}{$\begin{array}{l}\text { Array } \\
\text { peak } \\
\text { amp }\end{array}$} & \multirow{2}{*}{$\begin{array}{l}\text { Battery bank } \\
\text { capacity/(battery } \\
\text { efficiency x peak } \\
\text { sunshine) }\end{array}$} & $\begin{array}{l}472 \\
\text { Amph }\end{array}$ & \multirow[t]{2}{*}{87} \\
\hline & & & $0.9 \times 6$ & \\
\hline 6 & $\begin{array}{l}\text { Module } \\
\text { in } \\
\text { parallel }\end{array}$ & $\begin{array}{l}\text { Array peak } \\
\text { amp/peak amp per } \\
\text { module }\end{array}$ & $87 / 6.7$ & 13 \\
\hline \multirow[t]{3}{*}{7} & Module & System voltage/ & 230 & \multirow[t]{2}{*}{6} \\
\hline & in series & $\begin{array}{l}\text { nominal module } \\
\text { voltage }\end{array}$ & 39 & \\
\hline & $\begin{array}{l}\text { Total } \\
\text { No. of } \\
\text { PV } \\
\text { modules }\end{array}$ & $6 * 7$ & $6 \times 13$ & 78 panels \\
\hline
\end{tabular}

The theoretical calculations in table 3 show that to supply a load of 30MWh per year using a backup battery system, a total of 78 panels (20.28 KWp) out of 1062 panels is sufficient with a total of 60 batteries. Each Nano PV panel has a power of 260Wp while each battery has a capacity of $200 \mathrm{Ah}$ and each battery bank has a capacity of 472 Amph per day with 20 batteries in series and 3 batteries in parallel. These panels must be connected to an inverter that has more or equivalent power to $20.28 \mathrm{KWp}$ of 78 panels. The inverter that has been chosen for this design is from Huawei company (SUN2000-23KT) that has a maximum rated power of $23600 \mathrm{~W}$ with three maximum power point (MMP) trackers and each MMP trackers has 2 inputs. By taking into consideration that the maximum number of the NS-100B$260 \mathrm{~W}$ panel in series orientation is 38 panels based on table 2 data. Therefore, the system configuration for the battery system as follows: A total of 4 strings of NS-100B-260W type panel will be connected to the SUN2000-23KTL inverter. The MPP of the inverter will be connected as follows: MPP1 has two strings panel configuration, each string is connected to 19 panels, MPP2 has one string with 21 panels connected in series and MPP3 has one string with 19 panels. There will be three battery banks for a battery backup system. Each battery bank will consist of 20 batteries connected in series and connected to three single-phase $8.0 \mathrm{H}$ charge controllers since it covers a wide range of batteries capacities. The inverter with panels, charge controllers and grid are connected to a multi-cluster box. The layout diagram for a battery backup system of the above description is shown in figure 3 .

Now the system configuration for the other 984 NS-100B-260W panels was implemented with the help of the PVSOL premium 2018 simulator. The array comprises of 982 panels that are connected to 12 Sunny Tripower 20000TL-30 inverter. Each inverter has two MPP inputs. Each MPP input is connected to two strings. Each string is connected to 20 panels to 21 panels [22].

\subsection{Simulation result}

The simulation of the battery bank configuration result that a total of $32192 \mathrm{KWh} /$ year will supply the load with performance ratio of $83 \%$, system efficiency $96.9 \%$ and an amount of $18070 \mathrm{~kg} /$ year of CO2 has been avoided. SMA sunny design simulator verifies that total nominal capacity for the system needed to the supply the system for 24 hours is 5000Ah for each cluster bank batteries with $80 \%$ depth of discharge. The capacity of batteries differs from the theoretical calculation due to using different nominal battery voltage. While the simulation for the Grid-tie (984 panels) configuration result that PV system generates about $3.97 \mathrm{GWh} /$ year with a performance ratio of $85.3 \%$ and $288720 \mathrm{~kg} /$ year of CO2 emissions have been avoided. Figure 4 shows the maximum power generated from the PV system is from June, July, and August for both systems. 


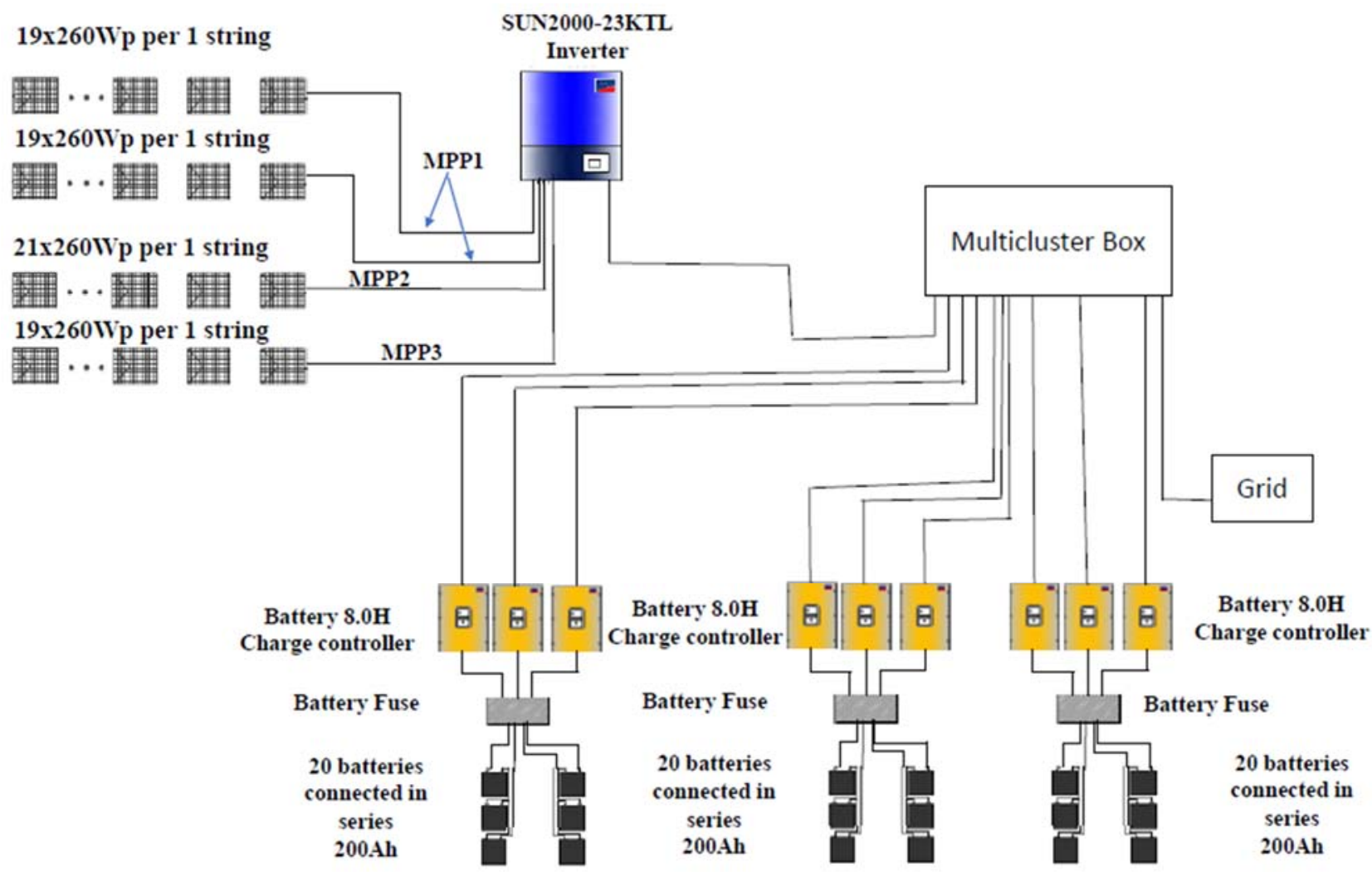

Fig. 3: Battery Bank Schematic Layout configuration

\section{Production Forecast}

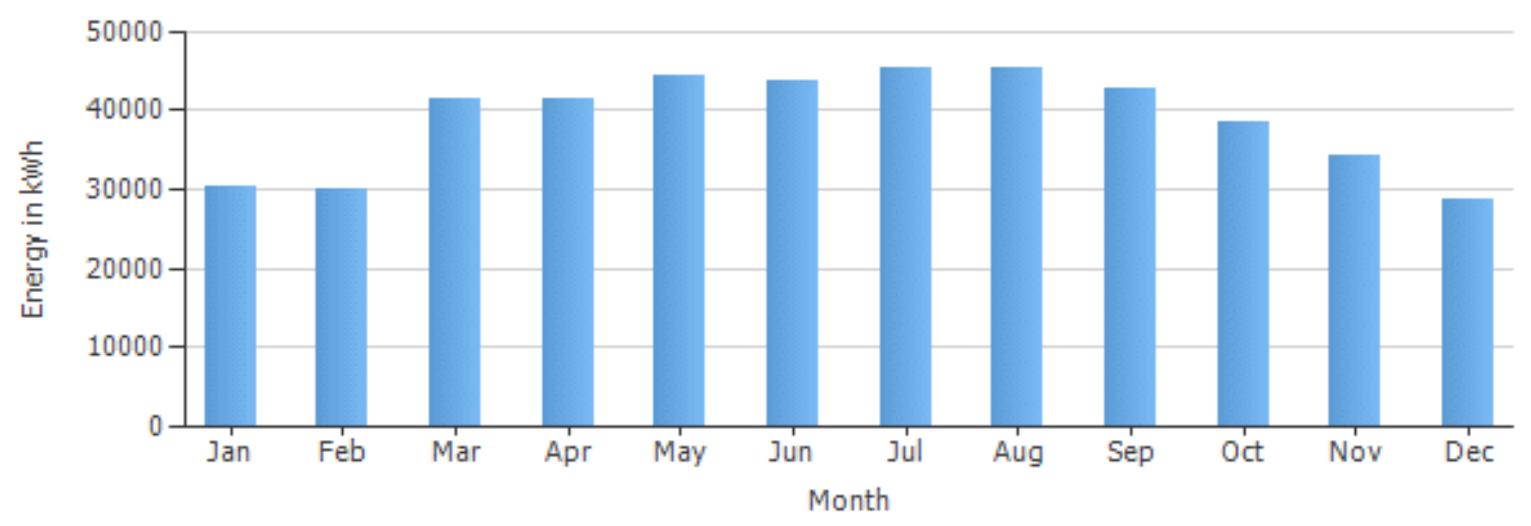

PV Generator Energy (AC grid)

Fig. 4. Maximum power generated from the PV system for a year. 


\subsection{System Orientation Result}

The PV modules will be fixed Tilted Plane on the top of the car park using the flash mount installation facing the south with an inclination with Plane tilt/azimuth: $30^{\circ} / 0^{\circ}$ [23].

\subsection{Economic Cost Analysis of Conventional panel used by AAU and CNT PV panel}

The comparison in table 4 revealed that standalone hybrid CNT PV system would reduce the total investment cost up to $21.12 \%$ when compared to the existing AAU system. While the payback period has been reduced from 10 years to 8 years.

Table 4: Economic Analysis

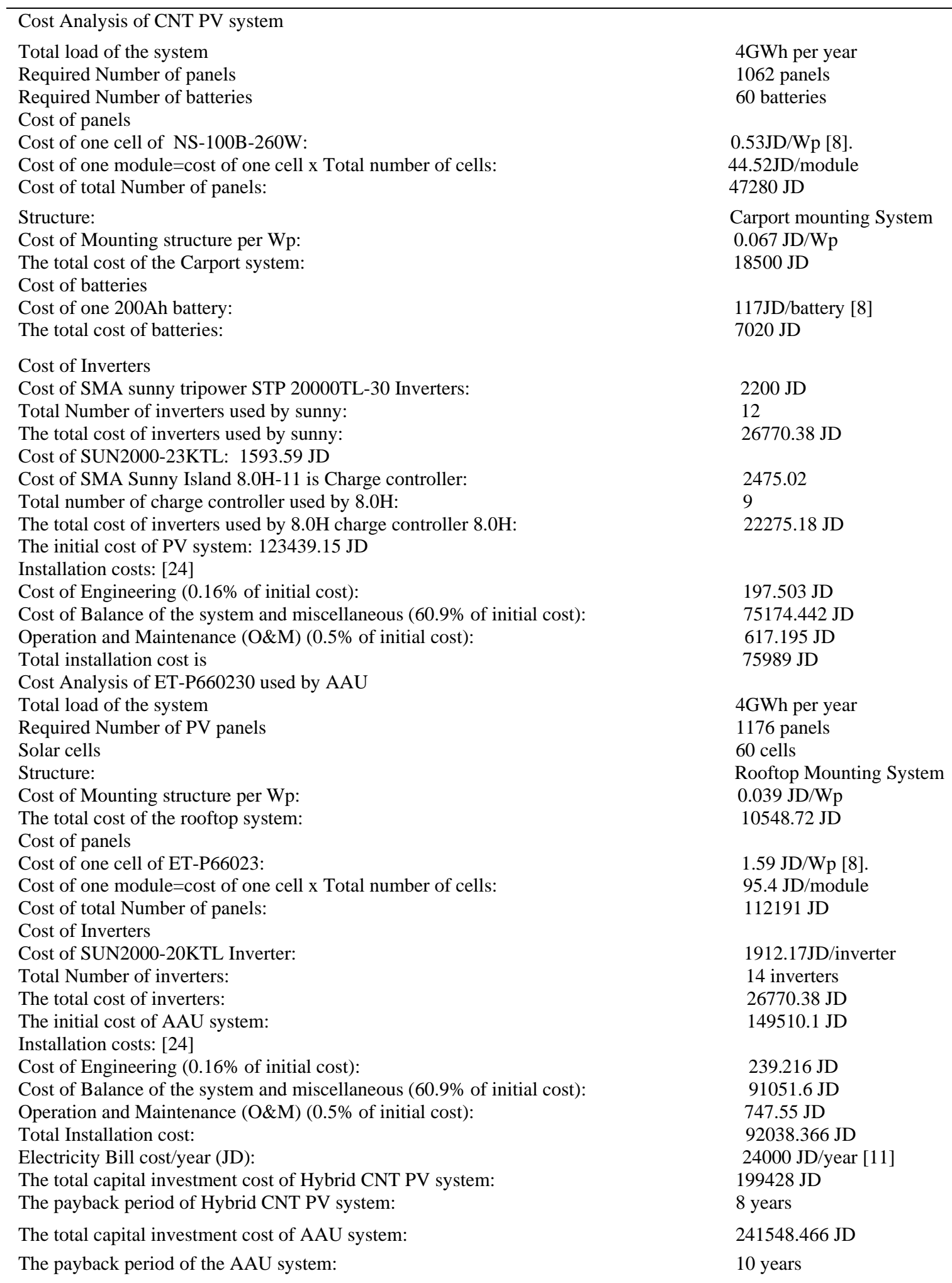

Capital cost reduction: 21.12 \% of the cost was reduced by using Standalone Hybrid CNT PV system 


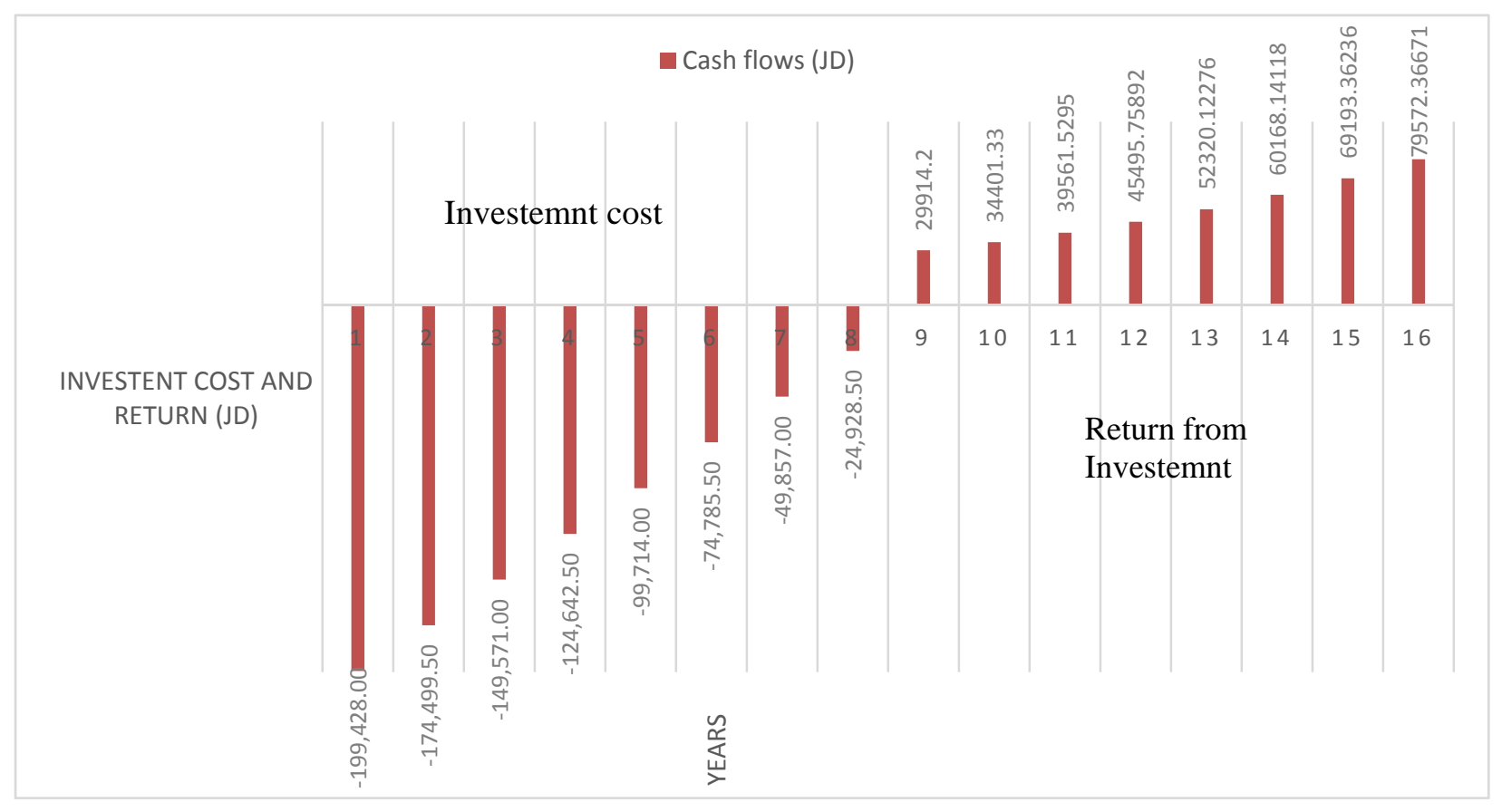

Figure 5 Accrued investment cash flow balance

\subsection{Internal Rate of Return}

The internal rate of return (IRR) is the rate (r) at which Net present value (NPV) of all future cash flows for a project is zero. The equation of NPV is as follow:

$$
\text { Net present value (NPV) }=\sum_{t=0}^{t} \frac{\mathrm{CF}_{\mathrm{t}}}{(1+\mathrm{r})^{\mathrm{t}}}-\mathrm{C}_{\mathrm{i}}
$$

Where,

$\mathrm{CF}_{\mathrm{t}}$ : annual revenue of the $\mathrm{PV}$ project during period $\mathrm{t}$

$r$ : Internal rate of return

$\mathrm{t}$ : lifespan of the system (years)

\section{$\mathrm{C}_{\mathrm{i}}$ : Capital cost of the project}

IRR can be found using Microsoft Excel program IRR function by setting NPV value to zero which is IRR (cash flows and initial investment, Interest rate). By assuming a tax rate of $15 \%$, an interest rate of $4 \%$ and the cash flows for 8 years period [19] are calculated using equation 9 and 10 :

Cash flow of Year $\mathrm{N}$

$$
\begin{aligned}
& =\text { Capital investment cost }(1 \\
& + \text { tax rate })^{\text {Year } N}
\end{aligned}
$$

Return from the investment

$$
=\text { Cash flow year } 1
$$$$
\text { - Cash flow year } 0
$$

Figure 5 shows the returned capital investment cost cash flows for the first 8 years and revenue money from the investment for the next 8 years from year 9 to 16 . As the first 8 years will be dedicated to the system investment return money with equal payment cash inflow of 24928.5JD each year. While the other 8 years will be the revenue money using the cash flows from the investment as it has been calculated using equation 9 and 10. For example, the cash flow for year 1 and year 2 and the benefit money from these two years as follows: flow year1 $=199428(1+15 \%) 1=229342.2 \mathrm{JD}$ and cash flow year2 $=199428(1+15 \%) 2=263743 J D$. The benefit of the investment=cash flow year 2 - cash flow year 1=34400JD.

As a result, all the investment cost will be returned back in the first 8 years while the benefit of the investment will start in year 9.

Now using the calculated cash flows of the investment shown in figure 5 to find IRR using the Microsoft Excel program IRR function, the result shows the IRR for this investment is $16 \%$ [19].

\subsection{Solar cell system efficiency}

A comparison between the performance efficiency of the CNT solar cell and AAU solar cell shown in table 5. Nano solar cell absorbs the maximum amount of photons since it is covered by thin layer anti-reflection coating material on the surface of the solar cell with a certain chemical called Carbon Nanotubes CNT. This chemical absorbs the maximum amount of photons by minimizing the reflections of the sun radiation, reduce the losses and increases the overall performance solar cell efficiency up to $31.25 \%$ higher than the AAU solar cell that has an efficiency of $14.14 \%$.

Table 5 Solar cell efficiency

\begin{tabular}{lll}
\hline \multirow{2}{*}{ Efficiency } & $\begin{array}{l}\text { The ET-P660235 solar cell } \\
\text { used by AAU efficiency is }\end{array}$ & $\begin{array}{l}\text { CNT solar } \\
\text { cell better } \\
\text { than ET- }\end{array}$ \\
& $\begin{array}{l}\text { P6.44\% [10] } \\
\text { The CNT solar cell efficiency } \\
\text { reaches 31.25\% [9] }\end{array}$ & $\begin{array}{l}\text { P660235 } \\
\text { solar cell }\end{array}$
\end{tabular}




\section{Conclusion and Recommendation}

This paper has overviewed energy efficiency solutions in several countries for the best solution to be implemented in AAU. The overview concludes that Standalone Hybrid CNT PV system is the most promising solution to supply AAU electrical demand. This solution was compared and examined with the existing system implemented in AAU based on design configuration, investment cost, solar cell efficiency and payback period.

The following conclusion, outcomes, and recommendations can be drawn from the present study: the simulation of the standalone Hybrid system result that PV system generates about 4.1 GWh/year with the performance ratio $84.3 \%$, efficiency $96.9 \%$ and an amount of $306790 \mathrm{~kg} /$ year of CO2 has been avoided. In addition, the total capital investment cost has been reduced to $21.12 \%$ by using Standalone Hybrid CNT PV system with a reduced payback period from 10 to 8 years when compared to the AAU project. Furthermore, CNT solar cell has an efficiency of $31.25 \%$ with lower manufacturing cost better than an ET-P660235 solar cell that has an efficiency of 14.14\%.

This standalone Hybrid CNT PV system can be applied to any commercial building. It also provides useful reference information for future standalone Hybrid CNT system design and operation. The benefits of using carport in this project, not rooftop because it maximizes the use of existing parking space to generate power, provide shade to protect vehicles from the heat and support the utility grid by feeding excess power generated.

\section{Nomenclature}

CNT Carbon Nanotubes

ECR Energy consumption ration

IRR Internal Rate of Return

\section{References}

[1] S. H. Mohr, J. Wang, G. Ellem, J. Ward, and D. Giurco, "Projection of world fossil fuels by country," Fuel, vol. 141, pp. 120-135, 2015.

[2] M. Krartia, Moncef; Alib, Fedaa; Alaidroosa, Alaa; Houchati, "Macroeconomic benefit analysis of largescale building energy," Int. J. Sustain. Built Environ., vol. 6, no. 2, pp. 597-609, 2017.

[3] P. McKenna, W. J. N. Turner, and D. P. Finn, "Geocooling with integrated PCM thermal energy storage in a commercial building," Energy, vol. 144, pp. 865-876, 2018.

[4] A. Aksamija, "Regenerative design and adaptive reuse of existing commercial buildings for net-zero energy use,” Sustain. Cities Soc., vol. 27, pp. 185-195, 2016.

[5] F. Baghdadi, K. Mohammedi, S. Diaf, and O. Behar, "Feasibility study and energy conversion analysis of stand-alone hybrid renewable energy system,” Energy Convers. Manag., vol. 105, pp. 471-479, 2015.

[6] M. Casini, Smart buildings advanced materials and nanotechnology to improve energy efficiency and environmental performance. 2016.
[7] D. Griego, M. Krarti, and A. Hernandez-Guerrero, "Energy efficiency optimization of new and existing office buildings in Guanajuato, Mexico,” Sustain. Cities Soc., vol. 17, pp. 132-140, 2015.

[8] P. Bhatt and A. Verma, "Design and Cost Analysis of PV System Using Nano Solar,” vol. 4, no. 3, pp. 1-7, 2014.

[9] B. Ashok Kumar, G. Sivasankar, B. Sangeeth Kumar, T. Sundarapandy, and M. Kottaisamy, "Development of Nano-composite Coating for Silicon Solar Cell Efficiency Improvement*,” Mater. Today Proc., vol. 5, no. 1, pp. 1759-1765, 2018.

[10] A. Hamzeh, S. Hamid, A. Sandouk, Z. Al-Omari, and G. Aldahim, "First-year performance of a PV plant in Jordan compared to PV plants in the region," Mediterr. Green Build. Renew. Energy Sel. Pap. from World Renew. Energy Network's Med Green Forum, vol. 5, no. 4, pp. 785-798, 2017.

[11] M. I. Al-Najideen and S. S. Alrwashdeh, "Design of a solar photovoltaic system to cover the electricity demand for the faculty of Engineering- Mu'tah University in Jordan,” Resour. Technol., vol. 3, no. 4, pp. 440-445, 2017.

[12] V. Shekar and M. Krarti, "Control strategies for dynamic insulation materials applied to commercial buildings,” Energy Build., vol. 154, pp. 305-320, 2017.

[13] M. Seifhashem, B. R. Capra, W. Milller, and J. Bell, "The potential for cool roofs to improve the energy efficiency of single storey warehouse-type retail buildings in Australia: A simulation case study," Energy Build., vol. 158, pp. 1393-1403, 2018.

[14] A. Muneeb, S. Ijaz, S. Khalid, and A. Mughal, "Research Study on Gained Energy Efficiency in a Commercial Setup by Replacing Conventional Lights with Modern Energy Saving Lights,” J. Archit. Eng. Technol., vol. 06, no. 02, 2017.

[15] Z. Zheng, Z. Zhuang, Z. Lian, and Y. Li, "Study on Energy Consumption Ration for Office Buildings," Energy Procedia, vol. 142, pp. 2317-2322, 2017.

[16] D. Christantoni, D. Flynn, and D. P. Finn, "Modelling of a multi-purpose commercial building for demand response analysis,” Energy Procedia, vol. 78, no. January 2016, pp. 2166-2171, 2015.

[17] D. Christantoni, S. Oxizidis, D. Flynn, and D. P. Finn, "Implementation of demand response strategies in a multi-purpose commercial building using a wholebuilding simulation model approach,” Energy Build., vol. 131, pp. 76-86, 2016.

[18] V. K. Sethi, M. Pandey, and P. Shukla, "Use of Nanotechnology in Solar PV Cell,” Int. J. Chem. Eng. Appl., vol. 2, no. 2, pp. 77-80, 2011.

[19] L. Al-Ghussain, "Economic Assessment of PV Investments in Jordan,” Innov. Energy Res., vol. 6, no. 2, pp. 1-11, 2017.

[20] F. M. Abdelhady, Salama Abd-Elhady, Mohamed, “No Title," Sciencedirect, pp. 466-475, 2017. 
[21] Y. Cai, L. Liang, and P. Gao, "Promise of commercialization: Carbon materials for low-cost perovskite solar cells,” Chinese Phys. B, vol. 27, no. 1, p. 018805, 2018

[22] A. K. Shukla, K. Sudhakar, and P. Baredar, "Design, simulation and economic analysis of standalone rooftop solar PV system in India," Sol. Energy, vol. 136, pp. 437-449, 2016.
[23] A. Karafil, H. Ozbay, M. Kesler, and H. Parmaksiz, "Calculation of optimum fixed tilt angle of PV panels depending on solar angles and comparison of the results with an experimental study conducted in summer in Bilecik, Turkey," ELECO 2015 - 9th Int. Conf. Electr. Electron. Eng., 2016, pp. 971-976, 2016.

[24] A. Alsheghri, S. A. Sharief, S. Rabbani, N. Z. Aitzhan, "Design and Cost Analysis of a Solar Photovoltaic Powered Reverse Osmosis Plant for Masdar Institute," Energy Procedia, vol. 75, pp. 319-324, 2015. 